\title{
Sports Betting in Indiana: The Proposed LEGISLATION AFTER MURPHY V. NCAA
}

\author{
PLACIDO A. ZAMBRANO
}

\section{INTRODUCTION}

Americans wagered $\$ 158$ million legally approximately $\$ 4.76$ billion on Super Bowl LII at the Nevada sportsbooks. ${ }^{1}$ The American Gaming Commission projected that across the United States, individuals wagered $\$ 4.76$ billion on Super Bowl LII and placed 97 percent of those total bets illegally. ${ }^{2}$ This estimate equated to more than $\$ 4.6$ billion in illegal sports betting. ${ }^{3}$ Nationwide, Americans illegally bet between $\$ 150$ billion and $\$ 450$ billion on sports every year. ${ }^{4}$ When the NBA Finals, the NFL Super Bowl, or the MLB World Series are underway, Indiana residents cannot legally place their bets on the game because in Indiana, placing a bet with a sports bookmaker is punishable as a level six felony. ${ }^{5}$ However, Hoosiers across the state still rush to call their illegal sports bookmakers and place their bets on upcoming sporting events. ${ }^{6}$

Betting illegally on sports might soon be a thing of the past for Hoosiers because of the recent Supreme Court decision in Murphy v. NCAA. ${ }^{7}$ Indiana residents are excited by the possibility of legal sports betting because now they can place their bets "away from the shadows of secrecy and stigmatization." Indiana casinos share that excitement; as Matt Bell, the President of the Indiana Casino Association, stated, "the [Murphy] decision creates an opportunity for

* J.D. Candidate, Indiana University Robert H. McKinney School of Law; B.A. 2016, University of Miami - Miami, FL. I would like to thank Professor Cooper, Amy Burbrink and Riley Parr for their invaluable insight, wisdom, and guidance throughout the Note writing process. I would also like to thank my family and friends for their unconditional support.

1. Jack Jones, How Much Money is Bet on the Super Bowl, BetFirm (Feb. 5, 2019), https://www.betfirm.com/amount-bet-on-the-super-bowl/ [https://perma.cc/W3F6-MF8F].

2. Thomas Barrabi, Super Bowl betting total to top $\$ 4.7 B$, with $97 \%$ bet illegally, Fox Bus. (Jan. 30, 2018), https://www.foxbusiness.com/features/super-bowl-betting-total-to-top-4-7b-with97-bet-illegally [https://perma.cc/52AW-GJ73].

3. Id.

4. See Niki Kelly, Legislators cram on sports betting, J. GAZETTE (June 10, 2018), http://www.journalgazette.net/news/local/indiana/20180610/legislators-cram-on-sports-betting [http://perma.cc/8HYQ-KASY].

5. See generally Mark Alesia, Here are questions about legal sports betting lawmakers must resolve before it becomes law, INDIANAPOLIS STAR (Nov. 26, 2018), https://www.indystar.com/ story/news/2018/11/26/sports-betting-indiana-faces-hurdles-along-path-becoming-legalgambling/1726863002/ [https://perma.cc/BTE5-EUY5]; see also IND. CoDE § 35-45-5-3 (2018).

6. Jerry Davich, Legalized Sports Betting in Indiana a Sure Bet for Hoosier Gamblers, CHI. TRIB. (May 22, 2018), http://www.chicagotribune.com/suburbs/post-tribune/opinion/ct-ptb-davichlegalized-gambling-inevitable-st-0523-story.html [https://perma.cc/4XP2-Z83S].

7. Murphy v. Nat'l Collegiate Athletic Ass'n, 138 S. Ct. 1461 (2018).

8. Davich, supra note 6. 
Indiana to create a regulated and transparent market that allows Hoosiers to legally participate in sports wagering" Amidst the statewide enthusiasm, the Indiana legislature will decide the future of sports betting in the state. ${ }^{10}$

The recent Supreme Court decision in Murphy has some Indiana state legislators celebrating at the prospect of finally being able to regulate the unfamiliar revenue-raising opportunity of sports betting. ${ }^{11}$ Experts estimate that within five years, sports betting in Indiana is likely to total bets of \$256 million a year, which translates to 2,281 direct and indirect new jobs and \$38 million in new state tax revenue annually. ${ }^{12}$ As Indiana Senator Ron Alting stated, "We're taking something that people are doing illegally today[,] and we are capitalizing on it by making it legal and regulating it[.]"13 In Indiana, legislators in both the House of Representatives and the Senate introduced sports betting bills in the 2018 legislative session before the Murphy decision. ${ }^{14}$ However, the 2018 Indiana legislative session closed with no vote on either bill. ${ }^{15}$ Indiana legislators estimated that a sports betting bill would be effective no earlier than July 1, 2019. ${ }^{16}$ Both Indiana Representative Alan Morrison and Senator Jon Ford stated that they would re-introduce the sports betting bill again in the 2019 legislative session. ${ }^{17}$ Currently, legislators are weighing the options for sports betting

9. See Andrew Steele, Casinos ready to bring sports betting to Indiana, Times Nw. IND. (May 17, 2018), https:/www.nwitimes.com/business/local/casinos-ready-to-bring-sports-betting-toindiana/article_c1a1b827-8d07-5778-b386-3af1 fa87b6a7.html [https://perma.cc/XU98-8HMX].

10. See Kelly, supra note 4.

11. See generally Indiana lawmakers to hold summer session on sports betting, TRISTATE (June 11, 2018), https://www.tristatehomepage.com/news/local-news/indiana-lawmakers-to-holdsummer-session-on-sports-betting/1232169301 [https://perma.cc/7ZHW-ZVVT].

12. Dan Carden, Odds looking good for legal sports betting next year in Indiana, TIMES Nw. IND. (Oct. 22, 2018), https://www.nwitimes.com/news/local/govt-and-politics/odds-looking-goodfor-legal-sports-betting-next-year-in/article_22bee61a-5657-54ba-a33e-189291edbcb7.html [https://perma.cc/6D93-22PK].

13. Kelly, supra note 4.

14. H.B. $1325,120^{\text {th }}$ Gen. Assemb., Reg. Sess. (Ind. 2018); S.B. 405 H.B. $1325,120^{\text {th }}$ Gen. Assemb., Reg. Sess. (Ind. 2018); see also Adam Candee, Movement in Indiana Sports Betting as Regulators Lookfor Help, LEGAL SPORTs REP. (Aug. 15, 2018), https://www.legalsportsreport.com/ 22965/movement-indiana-sports-betting-regulators-look-help/ [https://perma.cc/E6MF-HJVX].

15. Randolph DelFranco \& Julie Risgaard Mortensen, Sports Wagering: State-by-State Update for Tribal Entities with Gaming Compacts, Holland \& KNight (Oct. 10, 2018), https:/www.hklaw.com/en/insights/publications/2018/10/sports-wagering-statebystate-update-fortribal-ent [https://perma.cc/W2R2-Z9KN].

16. Ed Semmler, Expect sports gambling in Indiana and Michigan and a 'growth opportunity' for casinos, SOUTH BEND TRIB. (May 12, 2018), https://www.southbendtribune.com/ news/business/expect-sports-gambling-in-indiana-and-michigan-and-a-growth/article_0448dd1 d36a2-5380-88c3-a3d288f4d942.html [https://perma.cc/AF55-3FQ5].

17. Erica Irish, Indiana gaming regulators enlist market experts to study sports betting legalization, INDIANAPOLIS BUS. J. (Aug. 13, 2018), https://www.ibj.com/articles/70066-indianagaming-regulators-enlist-market-experts-to-study-sports-betting-legalization 
including where the betting will occur, how to tax and spend the revenue from the newly legal activity, and what sports are appropriate for betting. ${ }^{18}$

This Note argues that Indiana legislators need to pass legislation to legalize sports betting to take advantage of its enormous revenue-raising opportunity. Part I of this Note synopses the history of sports betting, the history of betting in Indiana, and the difference between fantasy sports and sports betting. Part II outlines the Murphy decision and the importance of the Tenth Amendment. Part III of this Note discusses the provisions that Indiana legislators should include in their 2019 Sports Betting Bill (the "Bill"). First, the Bill should include a provision that allows sports betting only at Indiana's fourteen licensed casinos, and four licensed betting facilities. Second, the Bill should include a provision that allows for online sports betting onsite at the casinos and offsite from casino websites or phone applications. Third, the Bill should include a provision that allows individuals to bet on any professional sports teams, but only collegiate teams that are not from Indiana. Fourth, the Bill should include a provision that allows the Indiana Gaming Commission ("IGC") to regulate sports betting. Part IV of this Note discusses the taxation framework that Indiana legislators should include in the Bill. First, Indiana needs to charge a $\$ 100,000$ licensing fee for any of the seventeen betting facilities that want to hold sports betting. Second, Indiana needs to tax the casinos and betting operators 9.75 percent of its sports betting yearly gross revenue from sports betting. Third, Indiana's taxation framework should not pay an integrity fee from its annual sports betting revenue to the professional leagues. Finally, Part V of this Note explores the implementation considerations that Indiana legislators need to consider before legalizing sports betting.

\section{THE HISTORY OF SPORTS BETTING}

\section{A. Why Is Sports Betting Illegal?}

To understand the importance of the Murphy decision legalizing sports betting, it is important to know why sports betting was illegal for so long. In the 1800 s, corruption led the federal government to ban nearly all forms of legal betting. ${ }^{19}$ However, betting on horse racing remained legal until the early $1900 \mathrm{~s}$ when many Americans developed a strong distaste for activities associated with the super-rich, including horse racing. ${ }^{20}$ The stigma against sports betting reached its peak in 1919 when eight members of the heavily favored Chicago White Sox allegedly intentionally lost the World Series against the Cincinnati Reds in exchange for a bribe of about $\$ 10,000$ apiece, which is the equivalent of

[https://perma.cc/D7PE-LHS9].

18. Kelly, supra note 4.

19. Aaron Gray, The History of Sports Betting Legislation in the USA (Part I), SPORTS BEtTing Dime (Aug. 3, 2018), https://www.sportsbettingdime.com/guides/legal/sports-bettinghistory-part-i/ [https://perma.cc/Y6BV-EBJX].

20. Id. 
approximately $\$ 150,000$ in $2019 .{ }^{21}$ The Great Depression made the legislature change its perspective on betting. ${ }^{22}$ To raise funds for the Hoover Dam Project, Nevada legalized gambling. ${ }^{23}$ The legalization of gambling in Nevada was a success, which led a group of sports bookmakers to request the state of Nevada to let it open sportsbooks in the state. ${ }^{24}$

The group of bookmakers succeeded, and in 1949, Nevada legalized sports betting. ${ }^{25}$ Moreover, the state gave the bookmakers permission and legal authority to accept bets on all professional sports (NFL, NHL, MLB, and the NBA), in addition to horse racing. ${ }^{26}$ However, in the 1960s outside of Nevada, organized crime continued to dominate the gambling and sports betting markets. ${ }^{27}$ In the 1960s and 1970s, Congress passed a series of laws trying to restrict illegal sports betting. ${ }^{28}$ But, illegal sports betting continued and increased in the 1970 s and 1980s when the United States Department of Justice decided to de-prioritize the enforcement of anti-gambling laws. ${ }^{29}$ Moreover, in 1976, the Commission on the Review of the National Policy Toward Gambling (the "Commission") stated that "gambling is inevitable," and enforcing laws against it was "impossible." Ultimately, the existing sports betting laws remained on the books, even if the government rarely enforced them. ${ }^{31}$

In the late 1980s, suspicious game-fixing scandals and the MLB's indefinite ban for then Reds Team Manager Pete Rose for betting on MLB games, created momentum for additional federal legislation aimed at eliminating or at least stopping the spread of sports betting. ${ }^{32}$ The federal government eventually passed

21. See Brett Smiley, A History of Sports Betting in the United States: Gambling Laws and Outlaws, SpORTS HANDLE (Nov. 13, 2017), https://sportshandle.com/gambling-laws-legislationunited-states-history/ [https://perma.cc/B65X-CE4X]; see also Calculate the Value of $\$ 10,000$ in 1919, DOLlaR Times, https:/www.dollartimes.com/inflation/inflation.php?amount=10000\&year= 1919 (last visited Mar. 19, 2019) [https://perma.cc/CVU5-PTBN].

22. Gray, supra note 19.

23. Id.

24. Aaron Gray, The Vegas Era: Major Sports Betting Legislation in the USA (Part II), Sports BetTing Dime (Aug. 3, 2018), https://www.sportsbettingdime.com/guides/legal/sportsbetting-history-part-ii/ [https://perma.cc/4KCA-2FMF]; see also Jeff Harris, What Is a Sportsbook? (And How Does Such a Business Make Money?), Gambling Sites (June 9, 2018), https://www.gamblingsites.org/blog/what-is-a-sports-book-and-how-does-such-a-business-makemoney/ [https://perma.cc/JVR7-X6TF]. A sportsbook is the same thing as a bookmaker, which is a company or individual who accepts bets on different sports from individual bettors. $I d$.

25. Gray, supra note 24.

26. Id.

27. Smiley, supra note 21.

28. Id.

29. $I d$.

30. Id.

31. Id.

32. Id. 
the Professional and Amateur Sports Protection Act of 1992 ("PASPA"). ${ }^{33}$ The PASPA was a federal law banning sports betting, despite most states already prohibiting it. ${ }^{34}$ The PASPA required states to tell Congress within a year whether they wanted to have sports betting within their borders. ${ }^{35}$ Since only four states applied for the PASPA's sports betting authorization, sports betting became illegal in most of the United States. ${ }^{36}$

\section{B. Indiana Through the Years}

The path to legal betting in Indiana began in 1988 when voters approved a lottery referendum by 62 percent. ${ }^{37}$ In 1989, the Indiana General Assembly ratified the Lottery Act, and the Hoosier Lottery offered its first legal lottery tickets for sale in October of $1989 .{ }^{38}$ Four years later, the Indiana General Assembly passed the Indiana Riverboat Gaming Act, which allowed for the construction of ten riverboat casinos. ${ }^{39}$ In 1995, the first of these ten riverboat casinos opened in Evansville, with excitement all around the city as the Dress Plaza horns were blasting, fire trucks horns on shore were blasting, and people lined the bank and peered through the windows of the city's high-rise buildings to get a glimpse of the new gaming destination. ${ }^{40}$ In 2004, the Indiana General Assembly passed legislation for the construction of the casino in French Lick, Indiana ${ }^{41}$ In 2007, the General Assembly passed legislation allowing 2,000 slot machines at each of the two horse racing tracks, which brought casino-type gaming to the cities of Shelbyville and Anderson in central Indiana. ${ }^{42}$ The term for the combined racing and casino properties is "racinos." ${ }^{43}$ In 2017, Caesars

33. Richard Johnson, The centuries-old history of how sports betting became illegal in the United States in the first place, SBNATION (May 18, 2018), https://www.sbnation.com/2018/ 5/18/17353994/sports-betting-illegal-united-states-why [https://perma.cc/Q26H-BXBB].

34. Id.

35. Id.

36. Id.

37. See Meg Jernigan, Indiana's Riverboat Casinos \& Hotels, USA TodAY (May 23, 2018), https://traveltips.usatoday.com/indianas-riverboat-casinos-hotels-56730.html [https://perma.cc/U5BZ-AZ8K]; see also History of Gambling, IND. U. (2018), https://ipgap. indiana.edu/resources-data/history-of-gambling [https://perma.cc/F39M-FMZR].

38. Id.

39. Jernigan, supra note 37.

40. Indiana's First Riverboat Casino Arrives in Evansville, Times Nw. IND. (Nov. 3, 1995), https://www.nwitimes.com/uncategorized/indiana-s-first-riverboat-casino-arrives-inevansville/article_8f6b1ca6-a769-52dd-8660-48a52a578788.html [https://perma.cc/K4KJ-BSRY].

41. See History of Gambling, supra note 37.

42. Id.

43. Dan Carden, Caesars' purchase of two Indiana racinos finalized, TiMES Nw. IND. (July 17, 2018), https://www.nwitimes.com/business/local/caesars-purchase-of-two-indiana-racinosfinalized/article_3562c932-ee33-5dbd-9be3-4b5e49c3ae28.html [https://perma.cc/ZF8Z-7WAA] (referencing "racinos" as properties that comprise both casino gambling and racing). 
Entertainment bought the racinos for $\$ 1.7$ billion and planned to invest $\$ 50$ million in various property improvements and IT upgrades at the properties. ${ }^{44}$ This acquisition of the racinos has increased the interest in Indiana as a major betting market, as Mark Frissora, president and CEO of Caesars Entertainment, stated: "Indiana will be our largest market after this acquisition, besides Nevada." ${ }^{" 45}$ Finally, in 2018, the Four Winds Casino opened in South Bend as the first casino in the state of Indiana owned and operated by a Native American tribe. ${ }^{46}$ In just a short twenty-five years, Hoosier bettors today can find games of chance at land-based, tribal and riverboat casinos, and at horse racing tracks with slot machines. ${ }^{47}$

As discussed Infra, after the Murphy decision, the states are now free to choose whether to legalize sports betting. ${ }^{48}$ Anticipating the decision, legislators in both the House of Representatives and the Senate introduced sports betting bills in the 2018 legislative session. ${ }^{49}$ The 2018 House of Representatives Bill 1325, introduced by Representative Alan Morrison, would have required a 9.25 percent tax on sports betting-related revenue and would allocate a 1 percent integrity fee to the sports leagues..$^{50}$ Representative Morrison's 2018 bill gained nationwide focus as Indiana became the first state to work with the professional sports leagues publicly. ${ }^{51}$ When asked about working with the professional sports leagues, Representative Morrison said working with the professional league would help with the integrity aspect of sports betting. ${ }^{52}$ Indiana State Senator Jon Ford also has introduced a bill aimed at legalizing sports betting, but Ford's bill did not include an integrity fee for the leagues. ${ }^{53}$ Ultimately, the 2018 Indiana legislative session closed with no vote on either sports betting bill. ${ }^{54}$

Following the 2018 Indiana legislative session, legislators decided to conduct a study of the implications of sports betting in Indiana. ${ }^{55}$ In August 2018, the General Assembly agreed to a two-year, \$74,999 contract with Eilers \& Krejcik

\section{Id.}

45. Id.

46. Four Winds Casino to open Jan. 16 in South Bend, South Bend TRIB. (Jan. 3, 2018), https://www.southbendtribune.com/news/local/four-winds-casino-to-open-jan-in-southbend/article_82905d1e-effc-11e7-8177-c39f7425a0b7.html [https://perma.cc/HVC7-MY93].

47. Jernigan, supra note 37.

48. See discussion infra Part II.A.

49. Candee, supra note 14.

50. H.B. 1325, $120^{\text {th }}$ Gen. Assemb., Reg. Sess. (Ind. 2018).

51. See David Purdum, Why Indiana is suddenly the center of the sports betting world's focus, ESPN (Jan. 19, 2018), http://www.espn.com/chalk/story//id/22153450/why-indiana-housebill-1325-important-future-legalized-sports-betting-us-gambling [https://perma.cc/5STJ-5NV7].

52. Id.

53. Id.

54. DelFranco \& Mortensen, supra note 15.

55. Andrew O'Malley, Uncertainty Surrounds Sports Betting Legalization in Indiana, VEGAS SLOTS ONLINE (Aug. 16, 2018), https://www.vegasslotsonline.com/news/2018/08/16/uncertaintysurrounds-sports-betting-legalization-in-indiana/ [https://perma.cc/F7FA-RRTJ]. 
to conduct a study for sports betting in Indiana.$^{56}$ In October 2018, after a fourhour session of a legislative study committee, lawmakers voted 9-0 to move forward with bringing legal sports betting to Indiana. ${ }^{57}$ During the session, the 142-page report, prepared by Eilers \& Krejcik Gaming, recommended that the state should enact legal sports betting during the 2019 legislative session. ${ }^{58}$ After the decision to move forward with sports betting, committee chair State Representative Ben Smaltz warned that there are still "many perils down the pathway before it becomes law." ${ }^{59}$ As legislators discover more information on sports betting, it is clear that the 2019 Indiana General Assembly's session will involve casino and gaming issues more than other sessions in recent years, including proposed bills for legal sports betting. ${ }^{60}$

\section{Sports Betting vs. Fantasy Sports}

Sports betting and fantasy sports are both based on real-life results of sporting events. ${ }^{61}$ However, daily fantasy sports are legal in the United States, while sports betting remained illegal until the Murphy decision. ${ }^{62}$ In fantasy sports, individuals choose real players in a draft or an online selection process to assemble a fantasy team. ${ }^{63}$ Then, the selected players' real-game statistics are compiled and compared to see whose fantasy team has done the best. ${ }^{64}$ In contrast, sports betting is the activity of predicting sports results and placing a wager on the outcome. ${ }^{65}$ Fantasy sports were ruled legal in a series of court decisions, which held that fantasy sports are legal because they are a game of skill, as opposed to sports betting which is a game of chance. ${ }^{66}$ Additionally, the Unlawful Internet

56. Candee, supra note 14.

57. Mark Alesia, Lawmakers move ahead on legal sports gambling, but know lots of questions remain, INDIANAPOLIS STAR (Oct. 19, 2018), https://www.indystar.com/story/news/2018/ $10 / 19 /$ egal-sports-gambling-betting-indiana-legis lature-study/1659216002/ [https://perma.cc/3LLT-AHVK].

58. Id.

59. Id.

60. Mark Alesia, Sports gambling, moving casinos will make gaming big part of upcoming legislative session, INDIANAPOLIS STAR (Dec. 31, 2018), https://www.indystar.com/story/ news/2018/12/31/indiana-legislature-gaming-sports-gambling-charity-gaming-papsa-integrityfee/2310182002/ [https://perma.cc/CD2L-KGM4].

61. Aaron Gray, Why Daily Fantasy Sports and Sports Betting are Legally Distinct, SPORTS Betting Dime (Aug. 3, 2018), https://www.sportsbettingdime.com/guides/legal/dfs-and-sportsbetting-legal-distinctions/ [https://perma.cc/ZK9T-SBNM].

62. Id.

63. Chris Isidore, Why fantasy football is legal, CNN Bus. (Oct. 6, 2015), https://money.cnn. com/2015/10/06/news/companies/fantasy-sports-legal/index.html [https://perma.cc/JZ8N-QURB].

64. $I d$.

65. Sports Betting, GLI, https://www.gaminglabs.com/sports-betting (last visited Nov. 21, 2018) [https://perma.cc/UBS5-NAS7].

66. See Isidore, supra note 63. 
Gambling Enforcement Act of 2006 excludes fantasy sports as an unlawful internet gambling activity as long as people are not betting on the outcome of a single game or the performance of a single player. ${ }^{67}$ This Note will focus on sports betting and not fantasy sports because Indiana already has legislation that allows for daily fantasy sports companies to operate, effective July 1, 2016. ${ }^{68}$

\section{LEGALIZED SPORTS BETTING LEFT TO THE STATES}

\section{$A$. Murphy v. NCAA}

In May 2018, the Supreme Court of the United States struck down the provision of the PASPA prohibiting state authorization of sports gambling schemes. ${ }^{69}$ In 1992, Congress passed the PASPA, to prohibit state-sanctioned sports gambling. ${ }^{70}$ The PASPA's anti-authorization provision said states could not "sponsor, operate, advertise, promote, license, or authorize by law or compact" sports gambling. ${ }^{71}$ The PASPA made exemptions for gambling in four states: Nevada, Delaware, Oregon, and Montana, which already had established sports betting regulations in place. ${ }^{72}$ New Jersey attempted to apply for the exemption but failed to act in 1991 before this exemption window closed. ${ }^{73}$ The New Jersey Legislature enacted the Sports Wagering Act ("2012 Act"), allowing sports wagering at New Jersey casinos and racetracks to help the casino industries in a faltering economy. ${ }^{74}$ However, professional sports leagues and the NCAA immediately challenged the 2012 Act. $^{75}$

In August 2012, the National Basketball Association ("NBA"), National Football League ("NFL"), National Hockey League ("NHL"), Major League Baseball ("MLB"), and National Collegiate Athletic Association ("NCAA") sued under the PASPA to strike down the New Jersey law. ${ }^{76}$ The district court and the Third Circuit Court of Appeals, in a split decision, found that the PASPA did not

67. Id.

68. Dustin Gouker, Indiana Becomes Second State to Pass Daily Fantasy Sports Regulation, LEGAL SPORTS REP. (Mar. 24, 2016), https:/www.legalsportsreport.com/9239/indiana-passes-dfsregulation/ [https://perma.cc/WX6H-E337].

69. Murphy v. NCAA, 138 S. Ct. 1461, 1481 (2018); see also Jill R. Dorson, What Is PASPA, The Federal Ban on Sports Betting?, SpORTSHANDLE (Feb. 13, 2018), https://sportshandle. com/what-is-paspa-sports-betting-ban-professional-amateur-sports/ [https://perma.cc/X25S-JERZ].

70. Murphy, 138 S. Ct. at 1470; see also Dorson, supra note 69.

71. 28 U.S.C. $\S 3702$.

72. Murphy, 138 S. Ct. at 1471.

73. Id.

74. Ariane de Vogue, Chris Christie goes to the Supreme Court on sports betting, CNN (Dec. 4, 2017), https://www.cnn.com/2017/12/04/politics/christie-scotus-sports-betting/index.html [https://perma.cc/TPF6-FEUB].

75. $I d$.

76. Erica L. Bishop, MURPHYv. NCAA, 138 S. CT. 1461 (2018), 45 OHIO N.U. L. REV. 239 (2019). 
violate the anti-commandeering rule of the Tenth Amendment. ${ }^{77}$ The decisions from the lower courts prohibited the state from enforcing the 2012 Act. $^{78}$ After the Supreme Court denied certiorari, the New Jersey legislature passed the Sports Wagering Act of 2014 ("2014 Act"). ${ }^{79}$ The 2014 Act repealed some provisions of the 2012 Act because it allowed casinos and racetracks to provide sports betting without the state's involvement in the licensing or regulating of sports betting, unlike the 2012 Act, which involved the state in licensing and regulating sports betting. ${ }^{80}$ In November 2014, the five leagues sued New Jersey again. ${ }^{81}$

The district court and Third Circuit Court of Appeals found that the 2014 Act violated the PASPA and that the anti-authorization provision did not violate the Tenth Amendment because it did "not command states to take affirmative actions." ${ }^{82}$ The Supreme Court granted certiorari to decide the important Tenth Amendment issue raised in the lower courts. ${ }^{83}$ The issue raised on certiorari by the petitioner, New Jersey, was whether "a federal statute that prohibits modification or repeal of state-law prohibitions on private conduct impermissibly commandeer the regulatory power of States." 84 New Jersey argued that the PASPA's anti-authorization provision violates the anti-commandeering rule of the Tenth Amendment and is thus unconstitutional..$^{85}$ The United States and the NCAA defended the PASPA's anti-authorization provision by arguing that the provision is a valid preemption of state law through the Supremacy Clause. ${ }^{86}$ Ultimately, the Court held that the PASPA's provision prohibiting state authorization of sports gambling schemes violated the anti-commandeering rule of the Tenth Amendment. ${ }^{87}$ The Court reasoned that the provision "unequivocally dictates what a state legislature may and may not do." 88 Therefore, the states are now free to choose whether to legalize sports betting. ${ }^{89}$

\section{B. Tenth Amendment Anti-Commandeering Doctrine}

Following the Murphy decision, the Supreme Court showed the importance

77. Murphy, 138 S. Ct. at 1471.

78. Id.

79. Id. at 1472 .

80. See Id.

81. Id.

82. Id. at 1473 .

83. Id.

84. Id. at 1488-89 (Ginsburg, J., dissenting).

85. Id. at 28 .

86. Murphy, 138 S. Ct. at 1479.

87. Id. at 1478 .

88. Id.

89. Ariane de Vogue \& Maegan Vazquez, Supreme Court lets states legalize sports gambling, CNN PoLiTiCs (May 14, 2018), https://www.cnn.com/2018/05/14/politics/sports-bettingncaa-supreme-court/index.html [https://perma.cc/T4YS-AGAF]. 
of the Tenth Amendment anti-commandeering doctrine. ${ }^{90}$ The Tenth Amendment states: "The powers not delegated to the United States by the Constitution, nor prohibited by it to the States, are reserved to the States respectively, or to the people." "T1 "The Constitution confers on Congress not plenary legislative power," but instead only certain enumerated powers, and the states have all other legislative powers. ${ }^{92}$ Since its decision in New York v. United States, the Supreme Court has declared laws unconstitutional for violating the Tenth Amendment when the federal government compelled or commandeered states to enforce federal statutes. ${ }^{93}$ The anti-commandeering doctrine represents the recognition of limits to the enumerated powers of congressional authority. ${ }^{94}$

Adherence to the anti-commandeering doctrine is important. First, the rule serves as "one of the Constitution's structural protections of liberty." 95 The anticommandeering doctrine protection of liberty provides a healthy balance of power between the states and the federal government and reduces the risk of tyranny. ${ }^{96}$ "Second, the anticommandeering rule promotes political accountability." $"$ For example, if Congress imposes regulations, then voters know who to credit or blame for the regulations. ${ }^{98}$ However, if a state imposes regulations only because it has been forced to do so by Congress, then voters do not know who to credit or blame for the regulations. ${ }^{99}$ Third, the anticommandeering principle "prevents Congress from shifting the costs of regulation to the States." ${ }^{100}$ For example, if Congress enacts a regulation, it must appropriate the funds needed to administer the program by weighing the expected benefits of the program against its costs. ${ }^{101}$ However, if Congress can compel the States to enact and enforce its program, Congress does not need to weigh the expected benefits of the program against its costs. ${ }^{102}$ As a result of the anticommandeering doctrine, states like Indiana can choose whether or not to legalize sports betting.

90. Ilya Somin, What Supreme Court victory for sports gambling means for marijuana, sanctuary cities, USA TODAY (May 15, 2018), https:/www.usatoday.com/story/opinion/2018/ 05/15/sports-gambling-supreme-court-federalism-marijuana-sanctuary-cities-column/610876002/ [https://perma.cc/XJB2-V9LD].

91. U.S. CONST. amend. X.

92. Murphy, 138 S. Ct. at 1476.

93. New York v. United States, 505 U.S. 144, 188 (1992) (holding that the "take title" provision of the Low-Level Radioactive Waste Policy Amendments Act violates the Tenth Amendment because it compels states to enact or administer a federal regulatory program).

94. Murphy, 138 S. Ct. at 1476.

95. Printz v. United States, 521 U.S. 898, 921 (1997).

96. New York, 505 U.S. at 206 (White, J., joined by Blackmun and Stevens, JJ., concurring in part, and dissenting in part).

97. Murphy, 138 S. Ct. at 1477.

98. Id.

99. Id.

100. Id.

101. Id.

102. Id. 


\section{INDIANA SPORTS BETTING LEGISLATION}

Currently, Indiana legislators are deciding the implications of legalizing sports betting. ${ }^{103}$ The biggest questions for legislators are where the betting will occur, whether to allow online betting, what sports are appropriate for betting, and who will be in charge of regulating sports betting. ${ }^{104}$ There are currently five states that have legalized sports betting including Nevada, Delaware, New Jersey, Mississippi, and West Virginia. ${ }^{105}$ By looking at what other states have done, Indiana legislators will have guidance on which provisions to include their Bill.

\section{A. Where Is Sports Betting Allowed?}

The first provision that the Bill should include is to allow sports betting only at Indiana's fourteen licensed casinos and four licensed betting facilities. As discussed infra, once the IGC grants these facilities their sports betting license, they will be able to offer a sportsbook. ${ }^{106}$ Allowing only licensed casinos or licensed betting facilities to conduct sports betting is the best approach for Indiana because this approach will provide a transparent sports betting market for the Hoosier state. ${ }^{107}$ Moreover, Indiana should only allow sports betting at Indiana's fourteen licensed casinos and four licensed betting facilities because every state that has legalized sports betting follows this approach. ${ }^{108}$

In Indiana, casinos are ready to offer sports betting, but they need the legislature to allow them to do so. ${ }^{109}$ Casino Association of Indiana President and CEO Matt Bell stated that "the [Murphy v. NCAA] decision creates an opportunity for Indiana to create a regulated and transparent market that allows Hoosiers to legally participate in sports wagering." ${ }^{110}$ Moreover, Troy Stremming, spokesman

103. Kelly, supra note 4.

104. See id.

105. Ryan Rodenberg, State-By-State Sports Betting Bill Tracker, ESPN (Oct. 15, 2018), http://www.espn.com/chalk/story/_id/19740480/gambling-sports-betting-bill-tracker-all-50-states [https://perma.cc/WC9L-FJUG].

106. See infra part III section D (discussing licenses).

107. See Karen Caffarini \& Meredith Colias-Pete, Northwest Indiana casinos roll with sports betting ruling, wait for Legislature to act, CHI. TRIB. (May 14, 2018), https://www.chicagotribune. $\mathrm{com} / \mathrm{suburbs} /$ post-tribune/ct-ptb-indiana-sports-betting-scotus-st-0 515 -story.html [https://perma.cc/W8NU-UZN9].

108. See Pete Blackburn, Wanna bet? Here's Where all 50 States Stand on the Legalization of Sports Gambling, CBS SPORTS (Jan. 2, 2020), https://www.cbssports.com/general/news/wannabet-heres-where-all-50-states-stand-on-the-legalization-of-sports-gambling/ [https://perma.cc/Y6B3-7LVS].

109. Lesley Weidenbener \& Lindsey Erdody, Indiana Casinos Want to Offer Sports Betting but Need State Lawmakers' OK, InDiAnAPOLIS Bus. J. (May 14, 2018). https://www.ibj.com/ articles/68813-indiana-casinos-want-to-offer-sports-betting-but-need-state-lawmakers-ok [https://perma.cc/6W3L-RBH9].

110. Steele, supra note 9. 
for Pinnacle Entertainment stated that "[c]asinos would provide sports betting with integrity guaranteed and in a more transparent manner." 111 Hoosiers who place bets can be prosecuted for a level six felony. ${ }^{12}$ In a recent survey, 52 percent of the Indiana residents that participated in the survey stated that they illegally place at least one sports bet per week. ${ }^{113}$ This provision will allow Indiana legislators to take sports betting out of the hands of illegal sportsbooks and make the sports betting market open and transparent. ${ }^{114}$

Indiana need only allow licensed casinos or licensed betting facilities to conduct sports betting because every state that has legalized sports betting follows this approach. ${ }^{115}$ Nevada allows sports betting only at licensed sportsbooks, which nearly every casino offers if the casino registers with the Nevada Gaming Commission. ${ }^{116}$ In Delaware, sports betting is limited to the state's three casinos, at least for the time being. ${ }^{117}$ Expanded sports betting options could take place at additional locations or online. ${ }^{118}$ As Governor John Carney described, Delaware's regulatory authority is "a full-scale sports gaming operation." 119 In New Jersey, every casino and racetrack in the state can offer sports betting, provided they are approved to do so by the New Jersey Division of Gaming Enforcement and the Casino Control Commission. ${ }^{120}$ In Mississippi, sports betting is limited to waterand land-based casinos. ${ }^{121}$ Additionally, any current gaming license holder can apply to the Mississippi Gaming Commission to offer sports betting. ${ }^{122}$ Finally, in West Virginia, lawmakers approved sports betting at the state's five casinos. ${ }^{123}$ Moreover, casinos can submit requests to West Virginia's Lottery Commission

111. Karen Caffarini \& Meredith Colias-Pete, supra note 107.

112. IND. CODE $\S 35-45-5-3$ (2018).

113. Eilers \& Krejcik Gaming, Regulated Sports Betting In Indiana: Landscape, AnAlysis, And Recommendations 103 (Oct. 2018) [perma.cc/W58S-4UA8].

114. Kelly, supra note 4.

115. See Blackburn, supra note 108.

116. Nevada Sports Betting, LEGAL SpORTS REP., https://www.legalsportsreport.com/nevada [https://perma.cc/VKV5-D8GH] (last visited Feb. 22, 2019); see also Nev. Gaming Comm. § 22.020 (2017).

117. Delaware Sports Betting, LEGAL SPORTS REP., https://www.legalsportsreport.com/ delaware [https://perma.cc/Y8AT-YK8W] (last visited Feb. 22, 2019).

118. Id.

119. Maya Salam, Delaware Kicks Off Full-Scale Sports Betting, a First Outside of Nevada, N.Y. Times (June 5, 2018), https://www.nytimes.com/2018/06/05/sports/sports-bettingdelaware.html [https://perma.cc/568L-6ZTZ].

120. New Jersey Sports Betting, Legal Sports ReP. (last updated Jan. 15,2020), https://www.legalsportsreport.com/nj/ [https://perma.cc/46Y8-ZLDR].

121. Mississippi Sports Betting, LEGAL SPORTS REP., https://www.legalsportsreport.com/ mississippi [https://perma.cc/4ZE6-H7B2] (last visited Feb. 22, 2019).

122. Id.

123. Sports Betting Makes Debut in West Virginia, ESPN (Aug. 30, 2018), http://www.espn. com/chalk/story/_id/24526698/sports-betting-makes-debut-west-virginia [https://perma.cc/3MU8DWMF]. 
for immediate commencement of sports pool or online sports pool operations. ${ }^{124}$ By following the approaches of other states, Indiana legislators can craft a topquality plan for their bill before the General Assembly adjourns for the year in March. ${ }^{125}$

\section{B. Online Betting}

The second provision that the Bill should include is to allow for online sports betting onsite at the casinos and offsite from casino websites or phone applications. Online betting is an important issue because recent studies estimate that online sports betting could be 40 to 45 percent of the sports betting marketplace. ${ }^{126}$ Allowing online sports betting onsite at the casinos and offsite from casino websites or phone applications is the best approach for Indiana because (1) it will allow Indiana to compete with the black market including offshore sportsbooks; (2) it will create more revenue for Indiana; and (3) it will allow Indiana to stay competitive with every state that has legalized sports betting and neighboring states who will legalize it in the future.

The Bill needs to include online sports betting onsite at the casinos and offsite from casino websites or phone applications because it will allow Indiana to compete with the black market of illegal sports betting. ${ }^{127}$ Though bettors will have the option to travel to a land-based casino to place legal bets, many could also opt for illegal betting unless the state allows for online betting platforms. ${ }^{128}$ In a recent survey, 71 percent of participating Indiana residents stated that they would not stop placing illegal bets if sports betting was only available at the nearest local casino, and there was no mobile application or website. ${ }^{129}$ In the same survey, 67 percent of Indiana residents stated that they place most of their illegal bets online. ${ }^{130}$ If online betting is not a part of Indiana's legislation, the president of the Casino Association of Indiana believes that the black market would continue to thrive. ${ }^{131}$ The online sports betting black market is an illegal, but profitable, sports betting operation run by foreign companies. ${ }^{132}$ Including online betting provisions in the Bill will help prevent individuals from opting for

124. Steven Allen Adams, West Virginia Lottery Releases Sports Bet Rules, THE INTELLIGENCER (July 12, 2018), http://www.theintelligencer.net/news/top-headlines/2018/07/westvirginia-lottery-releases-sports-bet-rules/ [https://perma.cc/4YF4-W543].

125. Carden, supra note 12.

126. Darren Heitner, 5 Pieces of Advice for States Considering the Legalization of Sports Betting, ForBES (July 15, 2018), https://www.forbes.com/sites/darrenheitner/2018/07/15/5-piecesof-advice-for-states-considering-the-legalization-of-sports-betting/\#59eab5f133 af [https://perma.cc/AVZ6-YZNW].

127. See generallyid.

128. Id.

129. EILERS \& KREJCIK GAMING, supra note 113, at 105.

130. $I d$.

131. Kelly, supra note 4.

132. Alesia, supra note 57. 
illegal options such as offshore sportsbooks to place their sports bets, and thereby prevent foreign companies from taking betting revenues that otherwise belong in this state. ${ }^{133}$

A provision in the Bill that allows casinos to offer online sports betting will allow Indiana to compete with offshore sportsbooks. ${ }^{134}$ The advantages provided by offshore sportsbooks are pricing, mobile/web-based platforms, online registration, and expansive betting options. ${ }^{135}$ Scott Cooley, an odds consultant for offshore sportsbook BetDSI, stated that "Offshore books . . . that almost exclusively cater to U.S. clientele will always have a place in the industry because there will always be a sector of gamblers that wish to remain anonymous and/or shop for the best odds." ${ }^{136}$ In other words, some level of black market activity is inevitable, but there are steps Indiana can take to limit the black market competition more effectively.

To compete with offshore sportsbooks, Indiana needs to offer the same level of access and advantages that offshore sportsbooks provide and capitalize on things that offshore sportsbooks cannot offer. ${ }^{137}$ First, allowing online sports betting onsite at the casinos and offsite from casino websites or phone applications will permit Indiana to offer the same access and advantage of offshore sportsbooks. ${ }^{138}$ As the Associate Director of the International Center for Gaming Regulation Jennifer Roberts stated, "[o]nce you legalize sports betting, it's not like everyone's going to shut down their accounts in the offshore market and suddenly start betting in a legal sportsbook, especially if there's not the same level of access or the 10 cent lines." 139

Second, to compete with offshore sportsbooks, Indiana needs to capitalize on things that offshore sportsbooks cannot offer such as a regulated payment dispute process provided by the IGC. ${ }^{140}$ Individuals who want to dispute payments from offshore sportsbooks face risks such as the sportsbook not having a dispute process, and the potential of the foreign government shutting down the offshore sportsbook. ${ }^{141}$ Moreover, by dealing with offshore sportsbooks, individuals will not have the ability to have a quality in-person customer experience such as a nice sportsbook lounge and free drinks. ${ }^{142}$ Ultimately, it is

133. Kelly, supra note 4.

134. Brett Smiley, What legal sports betting in the United States means for offshore sportsbooks, ESPN (Dec. 3, 2018), http://www.espn.com/chalk/story/_id/24028247/what-legalsports-betting-united-states-means-offshore-sportsbooks [https://perma.cc/X35K-QV38].

135. Id.

136. PJ Walsh, What Does the Future Hold for Offshore Sportsbooks?, ACTION NETWORK (May 20, 2018), https://www.actionnetwork.com/politics/article/offshore-sportsbooks-futurefollowing-sports-betting-legalization [https://perma.cc/6JGJ-PDYV].

137. See Smiley, supra note 134.

138. See id.

139. Id.

140. See id.

141. See id.

142. Smiley, supra note 134. 
difficult to foresee any scenario in which offshore sportsbooks disappear entirely, but allowing online sports betting only through Indiana Casino platforms will certainly have an effect in limiting illegal offshore sportsbooks. ${ }^{143}$

Online sports betting onsite at the casinos and offsite from casino websites or phone applications will also create more revenue for Indiana and its casinos. ${ }^{144}$ Indiana State Representative Alan Morrison stated: "It would be pretty important, moving forward with [sports betting], that we recognize the importance of mobile gaming and how it could really increase the revenue." ${ }^{145}$ For example, in Mississippi, online betting is allowed only inside casinos, and the total handle from August to September was $\$ 9.8$ million, which resulted in just $\$ 54,000$ in revenue for the state. ${ }^{146}$ In contrast, in New Jersey, which permits online and mobile betting, sports bettors placed more than $\$ 95$ million in total bets during August creating about $\$ 9.2$ million in revenue for casinos and racetracks. ${ }^{147}$ Moreover, New Jersey collected 8.5 percent of the casinos and racetracks' $\$ 9.2$ million, which generated a revenue of $\$ 765,000$ for the state. ${ }^{148}$ Additionally, the study by Eilers and Krejcik revealed that online betting could turn into the main driver of growth of the state's betting market and that if Indiana only legalizes betting in casinos and not online betting, the projected revenue will be approximately \$25 million less. ${ }^{149}$ If Indiana legislators do not include online sports betting at the casinos and offsite from casino websites or phone applications in their Bill, Indiana will be missing out on potential revenue like Mississippi and fail to maximize their revenue stream like New Jersey. ${ }^{150}$

Finally, Indiana should include online betting in its Bill to stay competitive with every state that has legalized sports betting and neighboring states who will

143. See Walsh, supra note 136.

144. David Williams, Sports betting in Indiana could arrive soon, lawmaker says, WISHTV (Aug. 14, 2018), https:/www.wishtv.com/news/indiana-news/sports-betting-in-indiana-couldarrive-soon-lawmaker-says/1368943978 [https://perma.cc/2YRP-B2G9].

145. Id.

146. Bobby Harrison, State revenue from sports betting $\$ 54,000$ in first month, Miss. ToDAY (Sept. 13, 2018), https://mississippitoday.org/2018/09/13/state-revenue-from-sports-betting-54000in-first-month/ [https://perma.cc/ALU9-34QE]; see also Sports Betting Handle vs. Revenue, THE LINES, https://www.thelines.com/sports-betting-handle-revenue (last visited Feb. 3, 2018) [https://perma.cc/JN6D-E4LJ] ("Handle" is the total amount of money wagered by bettors at a sportsbook over a given period, and "revenue" is the amount of money a sportsbook retains from total handle after paying out winners).

147. Eric Ramsey, New Jersey Sports Betting Generates Nearly $\$ 100$ Million in August Wagers, LEgAL SPORTS ReP. (Sept. 12, 2018), https://www.legalsportsreport.com/24005/newjersey-sports-betting-august-revenue/ [https://perma.cc/C7NT-RWXM].

148. Id.

149. Indiana Could See $\$ 466$ Million in Economic Impact from Sports Betting, CASINO NEwS (Oct. 21, 2018), https://www.casinonewsdaily.com/2018/10/21/indiana-could-see-466-million-ineconomic-impact-from-sports-betting/ [https://perma.cc/G3HC-KXKQ].

150. See Harrison, supra note 146; see also Ramsey, supra note 147. 
legalize it in the future. ${ }^{151}$ In Nevada, the sport betting laws require anyone registering for a mobile sports betting account to do so physically at a Nevada casino. ${ }^{152}$ Additionally, online sports bettors must be in Nevada to place a bet. ${ }^{153}$ In Delaware, current laws limit gambling to those physically present in a licensed casino, but state officials have indicated that they intend to consider expansion of online betting in the future. ${ }^{154}$ In New Jersey, the sports betting law includes provisions for casinos to permit online and mobile betting anywhere within the state's borders. ${ }^{155}$ Mississippi only permits online sports betting conducted onsite, which means that no mobile or online betting can take place outside a casino. ${ }^{156}$ West Virginia will soon allow for online and mobile sports betting, but individuals must be located within the state to place an online sports bet. ${ }^{157}$ Additionally, Kentucky, Illinois, and Ohio are expected to have legalized sports betting allowing for online sports betting in the next four years. ${ }^{158}$ As Indiana State Representative Alan Morrison stated, "[t]he ramifications ... would be on the state's casinos if neighboring states have legal sports gambling and Indiana does not." 159 By allowing for online sports betting at the casinos and offsite from casino websites or phone applications, Indiana can stay competitive with states that allow for online sports betting, and with neighboring states that will soon allow for online sports betting.

\section{Who to Bet on?}

The third provision the Bill should include is that any individual placing sports bets in Indiana are allowed to bet on any professional sports teams and any collegiate team except for Indiana collegiate teams. The reason behind this limitation is that professional leagues pay their athletes so much that they are unlikely to risk their careers by fixing games or shaving points, but college

151. See generally Blackburn, supra note 108 .

152. Adam Candee, Casinos Pitch for Fully Remote Registration of Nevada Sports Betting Mobile App Accounts, LEGAL SPORTS REP. (Oct. 16, 2018), https://www.legalsportsreport. com/24933/nevada-sports-betting-mobile-app-registration/ [https://perma.cc/9RMN-E9CJ].

153. Nevada Sports Betting, supra note 116.

154. Delaware Sports Betting, supra note 117.

155. New Jersey Sports Betting, LEGAL SPORTS REP., https://www.legalsportsreport.com/nj [https://perma.cc/E5QG-DK6S].

156. Mississippi Sports Betting, supra note 121.

157. Sports Betting Begins in West Virginia, Augusta Free Press (Sept. 24, 2018), https://augustafreepress.com/sports-betting-begins-in-west-virginia/ [https://perma.cc/62W965BD].

158. EILERS \& KREJCIK GAMING, supra note 113, at 16.

159. Mark Alesia, Indiana won't have legal sports betting soon, despite U.S. Supreme Court decision, INDIANAPOLIS STAR (May 14, 2018), https://www.indystar.com/story/news/2018/05/ 14/indiana-wont-have-legal-sports-gambling-soon-despite-court-decision/607178002/ [https://perma.cc/K5XC-XD7B]. 
players are vulnerable to illicit offers because they do not get paid. ${ }^{160}$ Additionally, there is a worry that gamblers, including classmates and neighbors, will try to acquire confidential data from insiders about injuries or academic standing to get a competitive edge. ${ }^{161}$ On the other hand, betting on college sports is a substantial revenue source; as Americans bet about $\$ 10$ billion every year in the NCAA men's college basketball tournament, and college football accounted for about 40 percent of all football bets placed in Nevada. ${ }^{162}$ Nonetheless, states like New Jersey that do not allow individuals to place bets in New Jersey on New Jersey collegiate teams have enjoyed economic success during the college football season. ${ }^{163}$ In September 2018, individuals in New Jersey bet $\$ 184$ million on sports (up from nearly $\$ 95$ million in August), giving state casinos \$24 million in revenue and the state $\$ 2$ million in tax revenue. ${ }^{164}$ In November 2018, New Jersey's revenue increased to $\$ 2.45$ million, with college and professional football accounting for $\$ 328$ million of the sports bets in the state since June. ${ }^{165}$ To strike a balance, a provision that allows any individual placing bets in Indiana to bet only on college teams that are not from Indiana will reduce risks of matchfixing and sharing of confidential information; it will also allow Indiana to enjoy the substantial revenue of college sports.

The Murphy decision has reignited the debate on whether the NCCA should pay their college athletes. ${ }^{166}$ Currently, college athletes are the most vulnerable athletes because they are unpaid, unlike professionals "whose multimillion dollar

160. Steve Berkowitz \& Erik Brady, Legalized sports betting will wreak havoc on college athletics. Or not., USA TODAY (May 31, 2018), https://www.usatoday.com/story/sports/college/ 2018/05/31/sports-betting-college-athletics-world-concerned-supreme-court-ruling/645367002/ [https://perma.cc/TRL2-WLHX].

161. Andrew Maykuth, What are the odds? Colleges fear sports betting will lead to cheating, LiNCOLN J. STAR (Sept. 18, 2018), https://journalstar.com/business/national-and-international/whatare-the-odds-colleges-fear-sports-betting-will-lead/article_12303375-200e-5832-a968f8flea76346b.html [https://perma.cc/HM43-WKBR].

162. Id.

163. See Wayne Parry, NJ Sports Betting: Football Gives Big Boost, COURIER Post (Oct. 12, 2018), https://www.courierpostonline.com/story/news/local/south-jersey/2018/10/12/nj-sportsbetting-latest-revenue-figures-released-atlantic-city-meadowlands/1615149002/ [https://perma.cc/Y5J7-WHSG]; see also, Marc Meltzer, No Hoops For You! New Jersey Bettors Limited On Local College Basketball Teams, The Lines (Nov. 9, 2018), https://www. thelines.com/nj-college-basketball-betting/ [https://perma.cc/6F9W-BABG].

164. Dustin Gouker, NJ Sports Betting Almost Doubles Total Amount Wagered in a Month: $\$ 184$ Million in September, Legal SpORTS ReP. (Oct. 12, 2018), https://www. legalsportsreport.com/24855/nj-sports-betting-september-revenue/ [https://perma.cc/E9H7-P3HL].

165. Nicholaus Garcia, New Jersey Sports Betting Revenue Pulled in a Record November Haul, PlayUSA (Dec. 13, 2018), https://www.playusa.com/new-jersey-sports-betting-november/ [https://perma.cc/E7HK-TLA6].

166. Sports betting? College Athletes are Vulnerable, Boston Globe (May 30, 2018), https://www.bostonglobe.com/opinion/editorials/2018/05/29/sports-betting-college-athletes-arevulnerable/HKN1FR52Ef7dBt7pKzyRbM/story.html [https://perma.cc/U2BW-LE54]. 
salaries should make them think twice about succumbing to corruption."167 The majority of college athletes have no chance of playing at the professional level, making them vulnerable to financial lures. ${ }^{168}$ Thus, if the NCAA paid their athletes, this section of analysis would allow for individuals placing a sports bet in Indiana to bet on Indiana college teams. However, whether the NCAA should pay their athletes is beyond the scope of this Note.

\section{Who Regulates Sports Betting?}

The Bill should include a provision that allows the IGC to regulate sports betting because it already has an existing casino licensing structure. ${ }^{169}$ The IGC should use its existing casino license structure instead of different stand-alone parlors to create a sports betting licensing structure and ease the sports betting transition in Indiana. ${ }^{170}$ As Senator Ron Alting stated, "[w]hy reinvent the wheel if you already have one?" "B1 By allowing the IGC to use its casino licensing structure, Indiana will mirror the Nevada licensing model, in which casinos need a sports betting license to allow people to place bets in their sportsbooks. ${ }^{172}$ Moreover, using Indiana's existing casino licensing structure to create a sports betting license structure will enable the state to move quickly to legalize sports betting, because the risks of delaying sports betting beyond 2020 outweigh the rewards. ${ }^{173}$

The Bill should include a provision that allows the IGC to regulate sports betting because the IGC has begun studying the implications of sports betting. ${ }^{174}$ The IGC is prepared to add sports betting to its portfolio should Indiana decide to legalize it. ${ }^{175}$ In August 2018, the IGC agreed to a two-year contract with Eilers \& Krejcik Gaming to advise legislators and regulators about the possibilities of Indiana sports betting. ${ }^{176}$ Moreover, IGC Executive Director Sara Tait stated that sports betting "is something that has been successfully regulated (elsewhere) for years, so we're not going to have to reinvent the wheel." 177 State Senator Ron Alting alluded that legislators want to write the best bill; by letting the ICG regulate sports betting, Indiana is one step closer to creating the best bill. ${ }^{178}$

167. $I d$.

168. Id.

169. Kelly, supra note 4.

170. Id.

171. Id.

172. See id.

173. See EILERS \& KREJCIK GAMING, supra note 113, at 127.

174. Candee, supra note 14.

175. Carden, supra note 12.

176. Candee, supra note 14.

177. Carden, supra note 12.

178. Id. 


\section{INDIANA SPORTS BETTING TAXATION FRAMEWORK}

\section{A. Licensing Fees}

Indiana legislators need to propose a $\$ 100,000$ initial licensing fee for any of the seventeen betting facilities that want to offer sports betting to generate substantial income and compete with the black market. ${ }^{179}$ A $\$ 100,000$ licensing fee will generate substantial income because states like New Jersey, which has a $\$ 100,000$ licensing fee, generated as much as $\$ 2.6$ million in tax revenue from sports betting in one month. ${ }^{180}$ Additionally, a $\$ 100,000$ initial licensing fee is not ridiculous, like Pennsylvania's proposed $\$ 10$ million initial licensing fee. ${ }^{181}$ Greg Carlin, CEO of Rush Street Gaming stated, "if legal sports betting is going to be a regulated and successful business, the tax rates can't be so high that it makes it impossible to compete with the black market." 182 Moreover, unreasonable licensing fees, like the $\$ 10$ million licensing fee in Pennsylvania, make casinos in the state hesitant to get in the sports betting industry feeding to the growth of the black market. ${ }^{183}$ A report by Eilers \& Krejcik found that "lower licensing fees will generally attract more license applicants and, in turn, yield higher levels of operator/supplier participation, whereas higher fees may attract fewer applicants and yield correspondingly lower levels of participation" by casino operators. ${ }^{184}$ In turn, the wider availability of sports betting in Indiana "will result in a greater transfer of demand from the black market to the regulated market." ${ }^{185}$ To generate revenue and compete with the black market, Indiana legislators need to propose a $\$ 100,000$ licensing fee.

One of the critical issues for Indiana legislators is what a reasonable sports betting licensing fee would be for casinos offering the service. ${ }^{186}$ A $\$ 100,000$

179. See generally Kelly, supra note 4; see also Grant Lucas, Extravagant Fees Turning PA Casinos Away from Sports Betting, PLAY PENN. (June 5, 2018), https://www.playpennsylvania.com/ sports-betting-fees-deterrent/ [https://perma.cc/MC4Y-ZS8P].

180. Gouker, supra note 164; see also New Jersey Sports Betting — Sportsbook Bonus Offers, Power Rankings, and Wagering Info, SPORTSHANDLE (last visited Jan. 4, 2020), https://sportshandle.com/new-jersey/ [https://perma.cc/288K-Q7JQ].

181. See Rick Rockwell, High Tax Rates Prevent Pennsylvania Casinos From Taking Sports Bets, GAMBLING SiTeS (June 14, 2018), https:/www.gamblingsites.org/news/high-tax-ratesprevent-pennsylvania-casinos-from-taking-sports-bets/ [https://perma.cc/56SQ-DLB4] (in his quote, Greg Carlin includes both licensing fees and yearly tax-rates when referring to tax rates).

182. A.J. Perez, High cost of launching sports betting in certain states could keep companies away, USA TODAY (May 17, 2018), https:/www.usatoday.com/story/sports/2018/05/17/sportsbetting-high-cost-opening-sports-books-avoid-states/614332002/ [https://perma.cc/C3HM-48AK].

183. Lucas, supra note 179.

184. See EILERS \& Krejcik GAming, supra note 113, at 87.

185. See id.

186. See Jill R. Dorson, After Spirited Hearing, Indiana Lawmakers Will Continue to Explore Sports Betting, SPORTSHANDLE (Oct. 19, 2018), https://sportshandle.com/indiana-sports-bettinghearing-101918/ [https://perma.cc/HMH5-K8VS]. 
licensing fee would be reasonable because other states that have legalized sports betting have implemented a similar fee. ${ }^{187}$ In Delaware, "[t]he state's three casinos function as a combined licensee, and they share the cost of licensure based on their slot contribution to the state." ${ }^{188}$ In New Jersey, an initial sports wagering license is $\$ 100,000$, which is renewable every year. ${ }^{189}$ In Mississippi, "any current gaming license holder can apply to offer sports betting."190 Moreover, each applicant for a license to conduct gaming must submit an application fee of $\$ 5,000$, and each licensee must pay an annual license fee of $\$ 5,000 .{ }^{191}$ In West Virginia, licensing fees are $\$ 100,000$ for a one-year term. ${ }^{192} \mathrm{~A}$ $\$ 100,000$ licensing fee is reasonable because it is similar to what three other states that have recently legalized sports betting have done, which is why Indiana legislators should propose it in their Bill. ${ }^{193}$

\section{B. Yearly Tax-Rate}

Indiana legislators need to implement a 9.75 percent tax rate on each casino's sports betting yearly gross revenue to create substantial revenue for the Hoosier state. During an October 2018 meeting, Matt Bell of the Casino Association of Indiana recommended Indiana legislators implement a single-digit tax rate. ${ }^{194}$ "The opening day of Delaware sports betting generated $\$ 322,135$ in handle." 195 Using an 8 percent tax rate, the Delaware handle will generate $\$ 1,423$ daily revenue and $\$ 519,395$ annual revenue. ${ }^{196}$ By using a 10 percent tax rate, Delaware will generate a handle of $\$ 1,778$ daily revenue and $\$ 648,970$ annual revenue. ${ }^{197}$ A report by Eilers \& Krejcik Gaming estimated that by using a 9.75 percent tax on gross revenue plus licensing fees for operators, Indiana's annual tax revenue from sports betting would be $\$ 38$ million in the fifth year. ${ }^{198}$ A 9.75 percent tax will generate substantial revenue for Indiana, as shown by Eilers \& Krejcik Gaming report, which states real-world examples like Delaware that use a similar

187. See EILERS \& KREJCIK GAming, supra note 113, at 88-89 tbls.

188. Delaware Sports Betting, supra note 117.

189. N.J. StAT. AnN. § 5:12A-11 (2019); N.J. Admin. Code $§ 13: 69$ N-1.3(a)-(b) (2019).

190. Mississippi Sports Betting, supra note 121.

191. Miss. Code AnN. § 75-76-183 (2018); see also EILERS \& KREJCIK GAMING, supra note 113 , at 88 .

192. Steven Stradbrooke, Mississippi, West Virginia okay sports betting regulations, CALVIN AYRE (June 21, 2018), https://calvinayre.com/2018/06/21/business/mississippi-west-virginia-sportsbetting-regulations/ [https://perma.cc/ZJF8-TUNG].

193. See supra notes 189, 191-192 and accompanying text.

194. See Dorson, supra note 186.

195. Adam Candee, How Much Do States With Sports Betting Stand To Make On Opening Day?, Play USA (June 14, 2018), https:/www.playusa.com/state-sports-betting-comparison/ [https://perma.cc/Z6G7-VLZZ].

196. Id.

197. Id.

198. Alesia, supra note 57; EILERS \& KREJCIK GAMING, supra note 113, at 5. 
yearly tax rate. $^{199}$

A 9.75 percent tax rate on casinos' sports betting yearly gross revenue will allow the state to compete with the black market. ${ }^{200}$ Setting high tax rates risks alienating customers, because the sportsbook operators might slightly increase the percentage deducted from the customers' winnings. ${ }^{201}$ The money deducted will "add up over time" and make customers "more likely to turn toward offshore websites or their local bookie to place their wagers." will not "get a cent of tax revenue" from those bets. ${ }^{203}$ The American Gaming Association estimates that Americans illegally bet $\$ 150$ billion in sports each year; if Indiana imposes a high tax rate, it will alienate customers and "ensure that the black market remains healthy."204

\section{Integrity Fees}

Indiana legislators need to pass a bill that pays no integrity fee from the state's sports betting yearly gross revenue to the professional leagues. Integrity fees are taxes on legal sports betting, which transfer money from the sportsbooks to sports' governing bodies. ${ }^{205}$ The NBA and MLB popularized the concept of integrity fees as the professional leagues try to find a way to profit from the rapid increase of sports betting in the United States. ${ }^{206}$ The professional leagues proposed the concept of integrity fees to the states, which would tax a sportsbook's handle at a rate of 1 percent, payable to each league on which sports wagering would occur. ${ }^{207}$ Later, the professional leagues brought the integrity fee rate down to 0.25 percent. Currently, no states have enacted integrity fees as part of their sports betting legislation, and Indiana was the only state to propose an integrity fee in 2018 with Representative Morrison's bill. ${ }^{208}$ The intended advantage of integrity fees is to bring legal, transparent sports betting to Indiana. ${ }^{209}$ However, professional sports leagues have existing incentives to

199. See EILERS \& Krejcik GAmING, supra note 113 , at 5, 81 \& 83.

200. $C f$. Johnny Kampis, Op-Ed: States should tread carefully in setting sports betting tax rates, WATCHDOG (Aug. 15, 2018), https://www.watchdog.org/national/op-ed-states-should-treadcarefully-in-setting-sports-betting/article_be 54cd26-9fc9-11e8-b220-8fc8710f49db.html [https://perma.cc/3T6G-YFLX] (stating that states should not "overtax the games, lest they chase bettors back into the black market.").

201. Id.

202. Id.

203. Id.

204. Id.

205. Sports Betting Integrity Fee, LEGAL SPORTS REP., https://www.legalsportsreport. com/integrity-fee/ [https://perma.cc/MQ7M-YFQD].

206. Id.

207. $I d$.

208. Id.; see also H.B. 1325, $120^{\text {th }}$ Gen. Assemb., Reg. Sess. (Ind. 2018).

209. David Purdum, Indiana House bill includes 1 percent 'integrity fee' for NBA, MLB, ESPN (Jan. 19, 2018), http://www.espn.com/chalk/story/_id/22006278/indiana-bill-includes- 
protect the integrity of their sporting events and do not need integrity fees as inducements for honest conduct. ${ }^{210}$

Indiana's bill should not include integrity fees because integrity fees take away from the state's revenue, hurt consumers, and hurt legal betting operators. To make integrity fees work, Indiana would likely have to lower its own revenue streams to pay the leagues, which would in turn hurt the state's revenue. ${ }^{211}$ Integrity fees will also hurt consumers because the cost of doing business will increase for legal sportsbooks, so they will likely attempt to pass that cost to consumers. ${ }^{212}$ Integrity fees will also hurt legal betting operators because an increase in the cost for customers will make it more difficult for legal betting operators to compete with illegal betting options. ${ }^{213}$ If the General Assembly decides to pass legislation that requires paying an integrity fee to professional sports leagues, Indiana's legislators will have abdicated their duty to prioritize Hoosiers and Indiana businesses.

Indiana's Bill needs to exclude an integrity fee because the professional leagues have not explained their need for the fee. ${ }^{214}$ Professional leagues have not asked for integrity fees in Nevada, where sports betting has been legal for decades. ${ }^{215}$ The professional leagues argue that the fee will go toward covering their increased cost burden to ensure integrity from legalized sports betting. ${ }^{216}$ However, the leagues would play no functional role in the sports betting industry because the states would regulate it, and the sportsbooks would operate it. ${ }^{217}$ Moreover, some question whether the lack of integrity fees means that professional leagues are not currently providing sufficient oversight. ${ }^{218}$ As Art Manteris, the VP of Race and Sport for Station Casinos stated, "So if they don't get paid, will they not provide integrity?"'219 Additionally, professional leagues have failed to discuss what leagues or organizations are entitled to a cut of the

integrity-fee-nba-mlb [https://perma.cc/M66W-J33G].

210. Peter Amsel, Major League Baseball first US league to sign up for sports betting data monitoring, CALVIN AYRE (Nov. 11, 2015), https://calvinayre.com/2015/11/11/sports/major-leaguebaseball-first-us-league-to-sign-up-for-sports-betting-data-monitoring/ [https://perma.cc/97QWMZY3]; see also Steve Ruddock, Gaming Experts Agree: Leagues Can't Explain Why They Need Integrity Fees, LEGAL SPORTS REP. (July 25, 2018), https://www.legalsportsreport.com/22190/ nclgs-integrity-fees-skepticism/ [https://perma.cc/U8YY-5JU8].

211. See Sports Betting Integrity Fee, supra note 205.

212. Id.

213. Id.

214. See Ruddock, supra note 210.

215. Paul Muschick, Sports world fought gambling but now wants money from it, MORNING CALL (July 7, 2018, 7:55 PM), https://www.mcall.com/opinion/muschick/mc-opi-sports-gamblingintegrity-fees-hypocrisy-muschick-20180705-story.html [https://perma.cc/53DL-VG9L].

216. Ruddock, supra note 210.

217. Sports Betting Integrity Fee, supra note 205.

218. Ruddock, supra note 210.

219. Id. 
fees. ${ }^{220}$ Would the integrity fees extend to USL, WNBA, IndyCar Racing, Motorsports, or the NCAA ${ }^{221}$ There are many questions that the professional leagues must answer before Indiana incorporates integrity fees into its legislation.

\section{IMPLEMENTATION}

\section{A. Match-Fixing}

The first implementation consideration Indiana legislators need to consider before legalizing sports betting is match-fixing. ${ }^{222}$ The three types of activities that individuals commonly associate with match-fixing are point shaving, tanking, and spot-fixing. ${ }^{223}$ In the aftermath of the Murphy decision, professional and collegiate leagues argue that without the federal protection of the PASPA, sports betting will expose its games and athletes to match-fixing, thereby creating a problem for state legislators. ${ }^{224}$

Most leagues are probably not susceptible to match-fixing because they do not have an issue with poorly compensated players or referees. ${ }^{225}$ However, collegiate-level sports may prove problematic with regard to match-fixing. ${ }^{226}$ The problem of collegiate-level sports lies with the NCAA, which does not allow for direct compensation beyond tuition and grants in aid for their student-athletes. ${ }^{227}$ The lack of compensation for student-athletes could leave them "particularly vulnerable to match fixers, especially if they were to come into a time of financial hardship."228 "A 2016 NCAA survey of more than 22,000 college athletes found nearly one-fourth of male athletes had violated NCAA rules by gambling on sports within the previous year." 229

220. $I d$.

221. See generally id.

222. John Holden, Match Fixing And Other Manipulations In Sports Betting: A Primer, LEGAL SPORTS REP. (June 4, 2018), https://www.legalsportsreport.com/20922/match-fixing-primer-sportsbetting/ [https://perma.cc/BD3L-W3C4] ("Match fixing is a broad term that incorporates a number of different activities that result in the manipulation of some aspect of a game, including the end result").

223. Id. ("[In point shaving,] the objective of the fix is to lose by less than the point-spread [but] not to lose the game itself. ... Tanking in the match-fixing context is generally described as a player or team intentionally putting in a sub-par effort. . . . Spot-fixing occurs when a player seeks to manipulate a specific event in a sporting event.”)

224. See John Wolohan, The potential impact of the Murphy v. NCAA decision on sports betting in the United States, LAwINSPORT (May 31, 2018), https://www.lawinsport.com/topics/ articles/item/the-potential-impact-of-the-murphy-v-ncaa-decision-on-sports-betting-in-the-unitedstates [https://perma.cc/25K3-A4SZ].

225. Holden, supra note 222.

226. Id.

227. Id.

228. Id.

229. David Porter \& Regina Garcia Cano, Easier gambling has sports worried about fighting 
Enacting a provision in the Bill that allows for individuals to bet only on college teams that are not in Indiana should reduce the risk of match-fixing. ${ }^{230}$ This provision in the Bill will reduce the worry that gamblers, including classmates and neighbors, will try to acquire confidential data from insiders about injuries or academic standing to get a competitive edge. ${ }^{231}$ Additionally, the state legislature could petition for the NCAA to pay athletes to reduce match-fixing concerns. ${ }^{232}$ The NCAA is a multibillion-dollar business that makes money off of athletes in the form of TV deals, ticket sales, and jersey sales. ${ }^{233}$ The NCAA paying student-athletes may not only be fair, but it could help end the matchfixing concerns. ${ }^{234}$

\section{B. Gambling Addiction}

The second implementation consideration that Indiana legislators need to consider is gambling addiction. An estimated 5.4 million Americans battle gambling addiction, yet 20 percent of states do not dedicate any funds toward gambling addiction. ${ }^{235}$ According to Marlene Warner, President of the National Center on Problem Gambling Board of Directors, "the expansion of legalized sports gambling in the United States will likely increase gambling participation and gambling problems unless steps are taken to minimize harm." ${ }^{236}$ As Neva Pryor, who runs New Jersey's Council on Compulsive Gambling stated, "[w]e're going to be adding fuel to the fire of an already serious problem.. ${ }^{237}$ In 2016, an estimated 1.2 percent of Indiana adults $(60,573)$ are believed to manifest a

the fix, DENV. Post (Sept. 17, 2018), https://www.denverpost.com/2018/09/17/sports-gamblingfighting-the-fix/ [https://perma.cc/PMA9-H7TP].

230. See Maykuth, supra note 161.

231. See id.

232. Cf. Scott Davis, The basketball world is convinced that the bribery scandal engulfing college basketball comes down to paying players, BUS. INSIDER (Sept. 28, 2017), https://www. businessinsider.com/college-basketball-bribery-scandal-paying-players-2017-9 [https://perma.cc/7P8B-32AZ].

233. Id.

234. Cf. id.

235. David Purdum, Are we doing enough to help problem gamblers?, ESPN (Sept. 19, 2018), http://www.espn.com/chalk/story/_/id/24722596/chalk-opponents-expanded-legalized-sportsbetting-think-helping-gambling-addicts-enough [https://perma.cc/R5D2-6578].

236. Cait Huble, National Council on Problem Gambling Statement on Supreme Court Ruling on Murphy v NCAA, NAT'L Council on Problem Gambling (May 14, 2018), https://www. ncpgambling.org/national-council-on-problem-gambling-statement-on-supreme-court-ruling-onmurphy-v-ncaa [https://perma.cc/7LL5-FX9S].

237. David Crary \& Wayne Parry, Expanded Sports Betting Fuels Fears About Gambling Addiction, U.S NEwS \& WORLD REP. (May 19, 2018), https://www.usnews.com/news/sports/ articles/2018-05-19/expanded-sports-betting-fuels-fears-about-gambling-addiction [https://perma.cc/UG2M-2XRX]. 
gambling problem. ${ }^{238}$ Thus, states that have proposed or will propose sports betting regulations are fearful about the potential increase of gambling addiction. $^{239}$

This note proposes two solutions to battle the gambling addiction in Indiana. The first solution is giving 1 percent of the state's sports betting yearly tax revenue to fund compulsive gambling programs, and the second solution is giving 50 percent of the casinos licensing fees to fund compulsive gambling programs. ${ }^{240}$ The National Council on Problem Gambling ("NCPG") wants any company, sports league, or government that benefits from sports betting to devote at least 1 percent of the revenue to fund programs that prevent and treat compulsive gambling. ${ }^{241}$ Moreover, the NCPG wants betting operators to train staff about problem gambling, to set and enforce a minimum age limit, and to enable gamblers to set limits on how much time and money they spend betting. ${ }^{242}$ Indiana could also follow New Jersey's approach, where the Division of Gaming Enforcement gives 50 percent of fees from sports betting licenses to the state's council on compulsive gambling. ${ }^{243}$ However, some New Jersey legislators think it is too early to identify any potential implications, like gambling addiction, from legalization of sports betting in the state. ${ }^{244}$ By proposing one of the two solutions, Indiana legislators can prevent overlooking the potential risks involved with sports betting. ${ }^{245}$

\section{Economic Ramifications}

The third implementation consideration that Indiana legislators need to consider is the economic ramifications of the Bill. The first economic ramification is the impact the Bill can bring to Indiana casinos. ${ }^{246}$ Caesars, owner of Horseshoe Casino in Hammond, bought two central Indiana racetrack and casino facilities previously owned by Centaur Holdings for $\$ 1.7$ billion. ${ }^{247}$ Mark Frissora, president and CEO of Caesars Entertainment, stated, "Indiana will be our largest market after this acquisition, besides Nevada."248 "Indiana Grand and

238. J. Marotta et al., 2016 Survey of Problem Gambling Services in the United States, Ass'N of Problem Gambling Serv. Admin. 1, 89 (2017), http://www.ncpgambling.org/wpcontent/uploads/2019/01/2016-Survey-of-PGS-in-US_FULL-REPORT-FINAL-12-19-2017-118.pdf [https://perma.cc/7L3W-YNBG].

239. See generally Crary \& Parry, supra note 237.

240. See id.; see also Purdum, Are We Doing Enough to Help Problem Gamblers?, supra note 235.

241. Crary \& Parry, supra note 237.

242. $I d$.

243. Purdum, Are We Doing Enough to Help Problem Gamblers?, supra note 235.

244. See id.

245. See id.

246. See generally Carden, supra note 43.

247. Id.

248. Id. 
Hoosier Park see more than 6.5 million guests combined each year and serve more than 1.1 million members as part of its loyalty program."249 Moreover, the president of Boyd Gaming, Keith Smith, said that he "views the expansion of sports betting as a growth opportunity." ${ }^{250}$ Boyd Gaming is in the process of purchasing Belterra Casino Resort \& Spa in southeastern Indiana. ${ }^{251}$ Indiana has a mature casino market with thirteen properties, and in 2017 had the fifth most revenue from gambling. ${ }^{252}$ Thus, Indiana legislators need to consider the economic impact of casinos because, with nearly 6.7 million residents, Indiana is a great market opportunity for all of the major casinos. ${ }^{253}$

The second economic ramification is the substantial positive economic impact that the Bill could bring to the Hoosier state. ${ }^{254}$ "According to Eilers and Krejcik, the legalization of both retail and online betting in the state could generate $\$ 56.2$ million in direct economic impact in year one." ${ }^{255}$ By the fifth year, "sports betting could generate $\$ 466$ million annually in statewide economic impact" if the Indiana General Assembly legalizes it. ${ }^{256}$ "Analysts project 729 full-time equivalent jobs by the fifth year." ${ }^{, 257}$ Moreover, additional revenue will benefit the state, as Indiana Representative Alan Morrison stated, "if we can add, say, \$20 million to the budget that wasn't there before, it's worthwhile."258 Indiana legislators need to consider the economic impact on the Hoosier state because a projected $\$ 466$ million annually in statewide economic impact is substantial. ${ }^{259}$

249. Christopher Stevens, Caesars Passes Final Hurdle to Acquire Hoosier Park, Indiana Grand, HeRALD Bull. (June 28, 2018), http://www.heraldbulletin.com/news/local_news/caesarspasses-final-hurdle-to-acquire-hoosier-park-indiana-grand/article_e4e6a3d2-b7a4-5546-bb8f034b1a831c92.html [https://perma.cc/NZ6B-3NJH].

250. See Semmler, supra note 16.

251. Id.

252. Megan Elliott, Hitting the Jackpot: These States Make the Most Money From Casino Gambling, CHEATSHEET (Nov. 26, 2017), https://www.cheatsheet.com/money-career/jackpot-thesestates-make-most-money-from-casino-gambling.html/ [https://perma.cc/LB65-TEPF].

253. See Candee, supra note 14.

254. See Scott L. Miley, Report: Sports betting could bring $\$ 466$ million impact to Indiana, Кокомо ТRIв. (Oct. 19, 2018), http://www.kokomotribune.com/news/report-sports-betting-couldbring-million-impact-to-indiana/article_cd2dcb18-d494-11e8-adfa-977bd61643bd.html [https://perma.cc/FG9T-HKJM].

255. Indiana Could See \$466 Million in Economic Impact from Sports Betting, supra note 149.

256. Miley, supra note 254.

257. Id.

258. Tim Anderson, No sure bets for states: Legal climate for sports wagering has changed, but impact in Midwest remains unclear as legislators weigh risks and benefits, CounCIL OF ST. Gov'Ts (Sept. 18, 2018), http://knowledgecenter.csg.org/kc/content/no-sure-bets-states-legalclimate-sports-wagering-has-changed-impact-midwest-remains-unclear [https://perma.cc/CUN4YQSU].

259. See Miley, supra note 254. 


\section{Marketing Strategies}

Sports fans and prospective sports bettors are certain to be greeted by massive advertising and marketing campaigns if a legal sports betting market becomes available. ${ }^{260}$ In Indiana, sports betting will be an important marketing tool as state casinos have seen recent years of declining revenue due to the "increased competition from surrounding states and tribal casinos." ${ }^{261}$ As Indiana is debating whether to legalize sports betting, casinos and licensed betting operators need to consider how they will use sports betting as a marketing tool to increase revenue and alienate the black market. ${ }^{262}$

Indiana casinos should use sports betting as a marketing tool by first sending an educationally focused message for less knowledgeable bettors to inform them on the illegality of offshore sportsbooks. ${ }^{263}$ The educational-based message will gradually appeal the less knowledge bettors to the recreational components of legalized sports betting, such as the social aspects of sports betting. ${ }^{264}$ The casinos' ads focusing on the recreational aspects of sports betting should also pop up on individuals' phones and computers, because "online advertisers are expected to outspend TV advertisers by $\$ 40$ billion this year." 265 Then, Indiana casinos should approach bigger, more data-driven and disciplined players, mainly through online advertising, to sway them away from offshore markets and their local bookmaker. ${ }^{266}$ Additionally, Indiana casinos should highlight the ease of using online platforms to sway both types of bettors away from offshore markets and their local bookmaker. ${ }^{267}$ The marketing of sports betting needs to have elements that appeal to both groups of sports bettors, and the casino that does this better will be the most profitable. ${ }^{268}$

Indiana Casinos should also use event marketing such as bar promotions, sporting events promotions, and sport team sponsorships to promote legal sports betting platforms. ${ }^{269}$ Indiana casinos can create marketing partnerships with sports

260. Robert H. Mann, What to Expect From the Coming Sports Betting Marketing Wave, SPORTSHANDLE (Apr. 10, 2018), https://sportshandle.com/sports-betting-marketing-advertisinglegal-us-market/ [https://perma.cc/X6F2-TK6D].

261. Tom Davies, Indiana lawmakers considering casino moves, sports betting, MiAMI HERALD (Feb. 10, 2019), https://www.miamiherald.com/news/business/article226062375.html [https://perma.cc/RT2W-BFNR].

262. See id; see also Mann, supra note 260.

263. See Mann, supra note 260.

264. See id.

265. Id.

266. $I d$.

267. Id.

268. See id.

269. See Patty Sins, How Sports Betting Companies Can Use Event Marketing to Find New Customers, ON THE AvENUE MARKETING (May 15, 2018), http://www.ontheavenuemarketing.com/ blog/2018/05/how-sports-betting-companies-can-use-event-marketing-find-new-customers [https://perma.cc/KT48-L4DF]. 
bars to target an audience that is already committed to watching sports. ${ }^{270}$ Casinos can offer bar patrons a gift card or other incentives in exchange for an online casino application download or a sports bet if the customer has the application already. ${ }^{271}$ Additionally, sports bars can create a themed night around sports betting to attract new customers to visit and find out more information about sports betting. ${ }^{272}$ Ultimately, it is difficult to foresee any scenario in which the black market and offshore sportsbooks will disappear, ${ }^{273}$ but Indiana should use marketing as a tool to promote legal sports betting and reduce access to the black market.

Indiana casinos should also market sports betting at select events that draw sports fan attendees, such as sporting events or beer festivals. ${ }^{274}$ The casinos should include an activation booth that incorporates a fun consumer promotion to encourage online casino application downloads and sports bets. ${ }^{275}$ Moreover, casinos trying to drive customers to their properties can distribute a "bounce back" coupon that includes a special offer that is effective only on-site. ${ }^{276}$ Finally, Indiana casinos can become the sponsor of a professional sports team to further draw fans who are already excited by the in-stadium experience to a compelling promotion that connects sports betting with their favorite team. ${ }^{277}$ By using event marketing, Indiana casinos can set themselves apart from competitors, grab new customers, and create a loyal sports betting customer base. ${ }^{278}$

\section{CONCLUSION}

In May 2018, the Supreme Court of the United States struck down the provision of the PASPA prohibiting state authorization of sports gambling schemes. ${ }^{279}$ The Court held that the PASPA's provision prohibiting state authorization of sports gambling schemes violates the anti-commandeering rule of the Tenth Amendment. ${ }^{280}$ The Court reasoned that the provision "unequivocally dictates what a state legislature may and may not do."281 Therefore, the states are now free to choose whether to legalize sports betting.

The Murphy decision has Indiana legislators weighing the implications of

270. See id.

271. Id.

272. Id.

273. PJ Walsh, What Does the Future Hold for Offshore Sportsbooks?, ACTION NETWORK (May 20, 2018), https://www.actionnetwork.com/politics/article/offshore-sportsbooks-futurefollowing-sports-betting-legalization [https://perma.cc/6JGJ-PDYV].

274. See Sins, supra note 269.

275. Id.

276. $I d$.

277. See id.

278. See Id.

279. Murphy v. NCAA, 138 S. Ct. 1461, 1478 (2018).

280. Id.

281. Id. 
sports betting including where the betting will occur, how to tax and spend the revenue from the newly legal activity, and what whether collegiate teams are appropriate for betting. ${ }^{282}$ This Note has argued that Indiana legislators need to pass legislation to legalize sports betting to take advantage of the enormous revenue-raising opportunity. ${ }^{283}$ To take advantage of the revenue-raising opportunity, this Note outlined the proposed Bill the legislation should pass. First, the Bill should include a provision that allows sports betting only at Indiana's fourteen licensed casinos, and four licensed betting facilities. Second, the Bill should include a provision that allows for online sports betting onsite at the casinos and offsite from casino websites or phone applications. Third, the Bill should include a provision that allows individuals to bet on any professional sports teams, but only collegiate teams that are not from Indiana. Fourth, the Bill should include a provision that enables the IGC to regulate sports betting.

This Note also discussed the taxation framework that Indiana legislators should include in the Bill. First, Indiana needs to charge a $\$ 100,000$ licensing fee for any of the seventeen betting facilities that want to hold sports betting. Second, Indiana needs to tax the casinos and betting operators 9.75 percent of their yearly gross revenue from sports betting. Third, Indiana's taxation framework should not pay an integrity fee from their annual sports betting revenue to the professional leagues. Finally, this Note explores different implementation considerations such as match-fixing, gambling addiction, economic impact, and marketing strategies that Indiana legislators need to consider before legalizing sports betting.

282. Kelly, supra note 4.

283. See Miley, supra note 254. 